\title{
Let's get started with targeted temperature management
}

\author{
Fabio Silvio Taccone \\ From Targeted Temperature Management (TTM 2014) \\ Berlin, Germany. 6-7 November 2014
}

Cardiac arrest (CA) remains a major cause of death and severe disability worldwide. The ischemic process that follows the cessation of cerebral perfusion and oxygenation, which is further worsened by the reperfusion injury occurring after the return of spontaneous circulation, can lead to severe hypoxic brain damage, resulting in a high rate of poor neurological recovery among CA survivors.

The use of mild therapeutic hypothermia, or targeted temperature management (TTM) as recently suggested [1], has been recommended in CA patients since the publication of two randomized clinical trials in 2002, the results of which demonstrated a significant improvement in neurologically intact survival for comatose CA patients presenting with ventricular fibrillation or ventricular tachycardia [1,2]. Current guidelines suggest that mild therapeutic hypothermia should also be considered in patients presenting with other rhythms, although this has been less well studied [3].

In experimental studies, TTM provided significant cardiac and neurological protective effects through different pathways. Hypothermic mechanisms providing myocardial protection include, amongst all, improved energy production during ischemia, increased calcium sensitivity of myocytes, regulation of mitochondrial oxidative phosphorylation and preserved myocardial vascular autoregulation $[4,5]$. All of these protective mechanisms would result in increased myocardial contractility. After a postanoxic injury, TTM may also protect cerebral function through reduced release of excitatory (that is, glutamate and dopamine) neurotransmitters, attenuation of reactive oxygen species production, preservation of the bloodbrain barrier, protection of cerebral microcirculation and decrease in intracranial pressure [6,7]. As several pathways are involved in the pathogenesis of extended post-anoxic brain damage, TTM can be considered as a general and nonspecific neuroprotective strategy, which may efficiently attenuate and mitigate most of these mechanisms and potentially improve patients' neurological outcome. Interestingly, recent studies have underlined not only that the hypothermic phase is important in this process, but that strict control of the patient's temperature during the first 3 days since hospital admission (that is, rapid achievement of target temperature, a precise control of temperature during the maintenance phase, a slow and controlled rewarming and avoidance of fever for 48 to 72 hours) are key components to enhance TTM effectiveness after post-anoxic brain injury [8].

\section{Financial disclosure}

FST received a research grant from Benechill in 2010 for animal research on IAHT.

\section{Declaration}

This abstract and supplement was proposed, developed and commissioned by BMC Emergency Medicine and was funded by an educational grant from C. R. BARD, NJ, USA. The published abstract was independently prepared by the author. C. R. BARD had no input into the content.

Published: 24 June 2015

\section{References}

1. Bernard SA, Gray TW, Buist MD, Jones BM, Silvester W, Gutteridge G, et al: Treatment of comatose survivors of out-of-hospital cardiac arrest with induced hypothermia. N Engl J Med 2002, 346(8):557-563.

2. Hypothermia after Cardiac Arrest Study Group: Mild therapeutic hypothermia to improve the neurologic outcome after cardiac arrest. N Engl J Med 2002, 346(8):549-556.

3. Deakin CD, Nolan JP, Soar J, Sunde K, Koster RW, Smith GB, et al: European Resuscitation Council Guidelines for Resuscitation 2010 Section 4. Adult advanced life support. Resuscitation 2010, 81(10):1305-1352.

4. Ning XH, Chen SH, Xu CS, Hyyti OM, Qian K, Krueger JJ, et al: Hypothermia preserves myocardial function and mitochondrial protein gene expression during hypoxia. Am J Physiol Heart Circ Physiol 2003, 285(1): $\mathrm{H} 212-\mathrm{H} 219$. 
5. Ristagno G, Tantillo S, Sun S, Weil MH, Tang W: Hypothermia improves ventricular myocyte contractility under conditions of normal perfusion and after an interval of ischemia. Resuscitation 2010, 81(7):898-903.

6. Karibe H, Zarow GJ, Graham SH, Weinstein PR: Mild intraischemic hypothermia reduces postischemic hyperperfusion, delayed postischemic hypoperfusion, blood-brain barrier disruption, brain edema, and neuronal damage volume after temporary focal cerebral ischemia in rats. J Cereb Blood Flow Metab 1994, 14(4):620-627.

7. Takasu A, Yagi K, Okada Y: Effect of mild hypothermia on ischemiainduced release of endothelin-1 in dog brain. Resuscitation 1996, 31(1):59-64.

8. Nielsen N, Wetterslev J, Cronberg T, Erlinge D, Gasche Y, Hassager C, et al: Targeted temperature management at $33^{\circ} \mathrm{C}$ versus $36^{\circ} \mathrm{C}$ after cardiac arrest. N Engl J Med 2013, 369(23):2197-206

doi:10.1186/1471-227X-15-S1-A1

Cite this article as: Taccone: Let's get started with targeted temperature management. BMC Emergency Medicine 2015 15(Suppl 1):A1.

\section{Submit your next manuscript to BioMed Central} and take full advantage of:

- Convenient online submission

- Thorough peer review

- No space constraints or color figure charges

- Immediate publication on acceptance

- Inclusion in PubMed, CAS, Scopus and Google Scholar

- Research which is freely available for redistribution

Submit your manuscript at www.biomedcentral.com/submit 